\title{
YOUTH UNEMPLOYMENT AND ITS REDUCTION MEASURES
}

\author{
Algis Šileika ${ }^{1}$, Valdas Rupšys ${ }^{2}$, Boguslavas Gruževskis ${ }^{3}$ \\ ${ }^{1}$ Vilnius Gediminas Technical University, Sauletekio al. 11, LT - 10223 Vilnius, Lithuania \\ E-mail: Algis.Sileika@dsti.lt. \\ ${ }^{2}$ Ministry of Social Security and Labour, A. Vivulskio g. 11, LT-03610Vilnius, Lithuania. E-mail: VRupsys@socmin.lt \\ ${ }^{3}$ Institute of Labour and Social Research, Rinktinès g. 48, LT-09318 Vilnius, Lithuania. \\ E-mail: Boguslavas.Gruzevskis@dsti.lt
}

Received 30 February 30; accepted 2 April 2004

\begin{abstract}
The efficient use of the labour force in post-industrial society predetermines the competitiveness of the economy and encourages social development. In this context, youth unemployment is a particularly undesirable phenomenon, reducing the efficiency of youth labour force within the level of general labour, raising social costs, and restricting social development. The position of young people on the labour market depends on a number of social, economic and demographic factors, leading to the conclusion that youth unemployment as a socio-economic phenomenon is a particularly negative result of the interaction between these factors. The aim of the paper is to discuss the theoretical assumptions of the youth integration to the labour market and to discuss the subsequences of their unemployment. Another target of the paper is to propose the policy measures for rising economic activity of the youth. The authors of the article suggest that the youth integration to the labour market could be increased by integrated decisions based on qualified services of vocational training.
\end{abstract}

Keywords: youth, employment, unemployment, policy measures, integration, labour market, vocational training.

\section{Introduction}

Competitiveness within the Lithuanian economy takes on a special significance amid economic restructuring and integration into the economic structures of the European Union. The quality of human resources, guaranteed by education and training at all levels, is one of most vital factors of economic competitiveness. The central requirements of today's economic and technological development, along with the challenges arising from euro integration, boosts the significance of labour force qualifications and provides a strong impetus for the intensification of social development. It should be noted that the efficient use of the labour force in post-industrial society predetermines the competitiveness of the product and encourages social development. In this context, youth unemployment is a particularly undesirable phenomenon, reducing the efficiency of youth labour force within the level of general labour, raising social costs, and restricting social development. The position of young people on the labour market depends on a number of social, economic and demographic factors, leading to the conclusion that youth unemployment as a socioeconomic phenomenon is a particularly negative result of the interaction between these factors. Following UN recommendations (Dolto, 1985, p.13; UN, 1986; UN, 1993), the category of youth covers those in the age group of 15 to 24 . However, different countries apply a different definition depending on cultural, institutional and political factors. Numerous countries favour linking the lower age with the age of graduation from school as required by law, while the upper age limit varies from country to country. Foreign countries require different age limits for young people in pursuit of national employment policies. For example, British youth employment policy usually targets individuals from 16 to 18 years old, whereas in northern and southern Italy the category covers individuals in the age group of 14 to 29 and 14 to 32 respectively (Seekings, 1993). In the United States the figures are from 16 to 24, and in Germany from 15 to 24 . Following Lithuania labour market policy, the category of youth is officially recognised as between 16 and 24 .

The problem of youth unemployment is the issue of the day the world over. With the exception of Austria 
and Germany, youth unemployment levels have exceeded the average figure almost two times in most European countries for a long time. In 2000, the level of youth unemployment in the EU ranged from 5.1 per cent in the Netherlands to 30.8 per cent in Italy ${ }^{1}$ (Employment in Europe, 2001). At the beginning of 21st century the level of youth unemployment in the EU exceeded the respective level in the United States two times, and surpassed the figure in Japan threefold. Youth unemployment exceeded the national average every year between 1991 and 2003 in Lithuania. According to the data of the Lithuanian Labour Exchange, average annual unemployment stood at 10.3 per cent, with youth unemployment at 13.4 per cent in 2003 (Activities of Lithuanian Labour Exchange in 2003. Vilnius, 2004). In the majority of cases, young people encounter structural unemployment predetermined by the non-compliance between the supply and demand of the labour force. To reduce the gap, the authorities need to coordinate the ratios of individual professions and qualifications within the labour market, adjusting vocational youth training (in the broad sense) to the needs of the labour market.

\section{Particulars of youth integration into the labour market}

Youth integration into the labour market is affected by a number of factors, including the development of services and manufacturing, education, work motivation, health, sources of household income, standard of living etc. These factors can be categorised according to different criteria subject to the objectives of studies.

According to foreign scientists (Blanchflower and Freeman, 1996; O'Higgins, 1995; Holm, Groes and Honore Olsen, 2001) engaged in the analysis of the processes of youth integration into the labour market, their position on it, which is similar to all other population groups, depends primarily on the general economic situation, in particular on aggregated demand. However, young people in search of their first job, including students, encounter many more problems than the unemployed (Berthelot, 1995). Thus young people are forced into the category of long-term unemployed. Moreover, young unemployed people may be condemned to long-lasting depression should they fail to turn their theoretical knowledge into practical ability, gain skills, and improve their professional competence.

Youth unemployment levels has been calculated as a percentage of the young (15= to 24) labour force (Eurostat methodology)
The analysis of trends of youth integration into the Lithuanian labour market should consider that, alongside socio-economic factors and a lower demand in the workforce, the higher level of youth unemployment, compared to other demographic, social groups of the unemployed, is predetermined by general level of education and vocational training. A significant section (approximately 42 per cent) of young jobseekers registered at labour exchanges have no professional qualifications.

The following three questions need to be answered in pursuit of an unbiased evaluation of the core reasons behind youth unemployment:

1. What are the reasons behind the fluctuations in youth unemployment?

2 . Why do youth unemployment levels fluctuate much more as compared to unemployment levels within the adult population?

3. What social and demographic qualities of unemployed young people boost or reduce employment possibilities?

First two questions are macroeconomic issues explaining general situation of young people within the labour market. The third question on the other hand is a microeconomic issue, specifying personal qualities that may have an impact on the employment of individual. Fluctuations in employment levels among young people are affected by the following three core factors: the demand within the youth labour force, remuneration, and the size and quality of the youth labour force.

\section{Demand within the youth labour force}

The impact of the aggregated demand on youth unemployment levels is identical to the impact on the general level of unemployment. Changes in the aggregated demand predetermine a decline in the demand for work in both young and adult employees, which is an undeniable and explicit fact. According to the trend in the effect on the market, a one per cent rise in unemployment among adults is accompanied by a two per cent rise in young people (Employing Youth, 1999). The question is why do these fluctuations in the aggregate demand have a disproportionate impact on youth and adult unemployment levels? Greater vulnerability of youth unemployment to the changes in aggregate demand, if compared with those of adult unemployment, is predetermined for a number of reasons. Young employees are likely to withdraw from work voluntarily quite often. The initial experience of young people on the labour market comprises of looking for 
a job in pursuit of suitable (complying with economic and social individual needs) activities. Usually young people have fewer skills, and they receive lower remuneration for their work. Primarily, work for young people not burdened with a family is an indication of a more effective satisfaction of their needs. Studies conducted by Blanchflower and Freeman (1996) revealed that young people aged between 16 and 25 had between seven and eight different jobs in the United States during those nine years. The number of voluntary redundancies of young people diminishes significantly as people get older. Young people, in particular those who maintain closer relations with their parents, are more likely to withdraw from work voluntarily than adults. Therefore, in the opinion of Blanchflower and Freeman, this is one of the reasons why the number of young unemployed people is greater than the number of the adult jobless population.

On the other hand, the dismissal of young people is much cheaper for companies, compared with older employees. Young employees with fewer skills represent a lower level of corporate training investment. Accordingly, companies incur fewer costs related to the dismissal of these employees. Moreover, numerous countries fail to guarantee their young population adequate employment protection legislation. These laws stipulate that an individual should have a respective qualification and work experience for these laws to be in effect for the awarding of benefits, the amount of which is closely related to the work record. Accordingly, firing recently hired employees is much cheaper. Obviously, it also has an impact on youth unemployment.

Studies have revealed that the first reaction of companies to economic decline is a suspension of their hiring programme until the necessity to begin costly redundancy procedures emerges. Obviously, in that case young people will make up a disproportionate segment of jobseekers, and will suffer much more significant impact on the suspension of hiring programmes. The above-mentioned reasons clearly explain why youth unemployment levels are much higher, and young people are much more vulnerable, compared with their adult partners (O'Higgins, 1997).

\section{Remuneration}

Some observers note that high financial reward for the work of young people is the reason of youth unemployment. Employers are not interested in hiring young people and paying them wages that do not reflect their capabilities. However, the policy that targets to reduce wages among young people in pursuit of a decrease in the level of unemployment among young individuals, may also be ineffective, which has been proved by OECD countries, which reduced wage levels in 1990 and witnessed a subsequent rise in the level of unemployment.

Wage levels affect youth employment. The higher the remuneration for work is among young people, the more companies tend to hire older employees. This is validated by the supposition that adults are the best or the closest replacements for young employees. However, in most cases this is untrue, in particular in the case of skilled employees. On the other hand, remuneration for the work of young people should not affect remuneration for the work of adults provided that both groups supplement each other within the labour market, for example, by demonstration of different work skills. In that case remuneration for work of young people and adults will affect their employment. Although remuneration takes up the main role, higher remuneration for the work of young people will have a definite impact on the decline in the level of employment among both young people and adults (O'Higgins, 1997).

Studies of youth unemployment conducted by Blanchflower (1999) have revealed a weak link between wages for the work of young people and adults and the respective levels of unemployment among them. With the exception of Sweden, wages among young people shrank in all OECD countries irrespective of the decline in the size of a young labour force and the diversity of domestic institutions that determine the amount of remuneration for the work of young people. It means that the beneficial impact of the decline in the size of a young labour force on wages was destroyed by other market forces. Blanchflower's studies have also revealed that minimum monthly wages do not provide any explanations for the poor economic situation among young people in OECD countries, either.

Discussions about proper public policy in Europe involved talks about the importance of the level of remuneration for work of both young people and adults, and the aggregate demand for the determination of the level of unemployment among young people. However, we should focus on the results of minimum wages on youth unemployment. Most studies have shown that aggregate demand is particularly significant for the determination of the level of unemployment among young people. However, the results of the study concerning the impact of wage levels are extremely complicated. Some studies have managed to trace the impact of remuneration on youth unemployment levels, whereas other studies have 
failed to locate the dependence. To a certain extent, the results depend on the differences in the structure of the study and the diversity of the information on remuneration. Previous studies showed an explicit relationship between youth unemployment and aggregate demand. However, they failed to establish a clear dependence between the remuneration for work of young people and the level of youth unemployment (Employing Youth, 2000).

Opponents of minimum wages object to the statement that high minimum wages boost youth unemployment levels, as they affect the costs of hiring young employees and raise the costs of work. Those in favour of minimum wages note that this argument is based on a false supposition about perfect competition between labour markets. However, if the labour market is monopsonic, companies may establish wages below the marginal labour product. Accordingly, a rise in minimum wages may lead to a rise in employment and predetermine a decline in unemployment respectively.

The question is: how much of monopsony should there be?

This question needs to be solved empirically, as a theoretical solution is impossible. Studies have failed to produce an explicit result, however, scientists have managed to prove that minimum wages have no greater negative impact on youth unemployment.

In 1996 Dolado et al. analysed the impact of the changes in minimum wages on employment in France, the Netherlands, Spain and the UK. The scientist established that changes in minimum wages had no impact on the employment of youth and adults in the UK and France. In the Netherlands however a decline in minimum wages for young people led to a slight increase in youth employment. Spain on the other hand showed just the opposite tendency, yet the changes of minimum wages had no impact on the adult employment. According to the analysis changes in minimum wages cannot become a foundation for a policy that targets the problems of youth employment (O'Higgins, 1997).

\section{Size of the labour force}

A rising number of young people within a labour market results in the need for a greater number of jobs. However, in some cases this explanation seems wrong amid signs of decline in the size of the youth labour force in the majority of European countries, including Lithuania. Extensive studies have revealed that the size of the youth labour force does have an impact on youth unemployment, although the influence of the conditions on the labour market is much more significant. For example, a 10 per cent rise in the population of young people within OECD countries predetermines a five per cent increase in the level of youth unemployment (International Labour, 1999). Steady economic development may reduce high youth unemployment considerably if young people have the sufficient skills and competences required within the labour market. The majority of European countries have witnessed a decline in the size of the youth labour force, a reduction that is expected to continue. However, this phenomenon will not solve the problem of youth unemployment on its own.

In 1999 Korenman and Neumark (Youth unemployment, 2000) established that the youth population reduced in all OECD countries between 1980 and 1990. A reduction in the size of youth labour force should lead to lower levels of unemployment and increased youth earnings. However, the economic situation of young people has in fact deteriorated. The failure of demographic changes to improve the situation among young people does not signify that the changes in supply have no impact on the youth labour market. The flexibility of youth unemployment levels is high enough, meaning that other factors such as the general level of unemployment or technological changes produce a significant influence on youth employment.

Young people with less experience than adults spend more time looking for work and adapting to their new working environment.

Young employees have little time to look for work in developing countries that offer no unemployment benefits and have low standards of living. Accordingly, young people are forced into taking up low capacity or occasional jobs to earn a living. We can conclude that higher employment levels among young people in developing countries are achieved at the expense of the quality of life of this group of the population.

The significance of work skills among young people for integration into the labour market

Qualifications and skills acquired by young people are an important factor predetermining their employment. Studies show that the employment results depend on the quality of education and professional training, as well as the compliance thereof with the needs and possibilities of the labour market. The following mechanisms are applied to alleviate the transition of young people from school to the working world: apprenticeship, additional training, and the inclusion of students into the labour market.

The introduction of new technologies boosts the 
demand for employees with high qualifications, levels of education and work skills. A country with a rising demand for young educated people may expect an improvement in youth employment. The period between young people leaving school and finding work tends to increase, and the people who have found work strive to withstand all the challenges of this temporary period of 'unsafe employment'. The main objective of public policy is to provide young people with proper education, training and support programmes that can lead to a reduction in social insecurity and hardships emerging during the period of transition, and to alleviate the long-term entry of young people into the labour market. Education levels cannot be treated as the sole reason behind the differences in unemployment levels among young people and adults, as the impact of education on youth unemployment is not direct. Young people who leave school early in developed countries find higher unemployment levels. In developing countries such as Indonesia, Jordan or Thailand, unemployment levels among people with a higher level of education exceed that of people with no education. However, the trend does not seem to justify itself in other countries, e.g., in Paraguay. The level of unemployment among Indonesians, who have compulsory education and take up low capacity or hazardous jobs, is lower compared with the level of unemployment among persons with secondary and professional education, the skills of whom may not comply with the demand of the labour market. However, the quality of education and training does have an impact on youth employment (Youth Unemployment, 2000).

\section{Consequences of youth unemployment}

Although youth unemployment levels are higher than those among the adult population, the consequences of youth unemployment are less painful when compared to those of older people. The supposition is that negative impact of unemployment tends to increase with the duration of unemployment. Material hardships as well as physiological and psychological damage grow considerably during the course of unemployment. Young people come across higher unemployment in different sectors, but the duration of their unemployment is shorter than that of adults. Long-term unemployment levels among young people are lower than those of adults in almost all OECD and European countries. Moreover, the differences between unemployment levels in different countries are much more significant compared with the differences between age groups within a single country.

Although the duration of unemployment among young people may be shorter than that of adults, young people should enjoy the particular attention of employment policy. Unemployment at the early stage of the working life of an individual may cripple the employment beliefs of that young person and damage his or her employment possibilities. Studies are easier for young people due to the particulars of human nature. Thus, the behaviour acquired in early life prevails during the rest of one's life. Depriving young people of the chance to acquire work experience and access education or professional training increases their hardships when looking for a job and actively participating in public life. Depriving a young person access to the working world of adults due to a lack of work skills is yet another grave consequence of unemployment and social insecurity among young people, which may demoralise young individuals, destroy their social relations and lead to numerous other social problems, including, but not limited to, drug abuse, vandalism, general alienation and social exclusion.

\section{Measures for integrating young people into the labour market}

Employment is an important part of society, securing an economic foundation for the existence of the individual and simultaneously predetermining the social status of that individual. Integration into the labour market meets with success provided that the differences between youth and adult employment are eliminated, while the rights, duties and possibilities offered to young people within the labour market are the same as those of adult employees. Integration is deemed to succeed in cases where youth employment does not differ from that of adults, when the possibilities offered to young people within the labour market are identical to those of adults, and young people have no impact on material and social life, as well as on the public standing of a young person. Thus, we may reach the conclusion that the integration of young people into the labour market signifies the following:

- The successful entrance of young people into the labour market (employment)

- Equal possibilities for both young people and adults to participate within the labour market

- The implementation of a purposeful national economic and social policy

As mentioned above, youth employment, similar to other age groups of the population, depends primarily on the general economic situation, the level of work relations, the efficiency of professional training 
systems, and general standards of living. However, young people should be included in a specific group within the context of employment policy, enabling us to discuss the specific features of successful integration of young people into the labour market. This successful integration is predetermined by the following factors:

- Programmes and public policy

- Encouragement of youth business

- Labour market information and vocational guidance

\section{Programmes and public policy}

The objective of programmes implemented by labour market policy institutions and other organisations is to improve the quality of youth education and professional training (in the broad sense), to boost employment and secure the acquisition of a profession enabling competition within the labour market. The following particulars of education and professional training programmes may be discerned within the context of the raising of youth employment:

- Successful programmes enabling a reduction in the number of people leaving school before graduating and helping them to return

- The application of programmes helping determine new methods for the transition from school to the world of work, establishing closer ties between education, training and work experience. Relationships between schools and employers are developed

- The creation of programmes in pursuit of expanding the possibilities of the state and other social institutions to solve the problems of unemployment among young people

To ensure a positive impact of education and training on youth employment, it should be properly arranged and well-organised, i.e., focused as much as possible on the following:

- Economic needs

- The needs and possibilities of young people (households)

- The systemic process of social human development

The authorities should use a certain mechanism of economic and social stimulation capable of encouraging young people to invest in education, which should develop into the main trend of youth employment programmes and public employment policy
Macroeconomic strategies affecting public labour demand and microeconomic strategies having an impact on labour supply assume the main role in the improvement of the position of young people on the labour market. As mentioned above, the problem of youth unemployment is associated with, and cannot be separated from, the problems encountered by the country attempting to reduce general employment levels.

\section{Encouragement of youth businesses}

Most emerging economies encourage youth enterprise or business, which is seen as a particular form of training. Although this measure cannot be treated as a universal way of reducing youth unemployment, business may contribute to the reduction of unemployment among young people and improve employment within this social group. The main objectives of business programmes targeting young people are the development of proper skills, business consulting and help during the first stages of business expansion. Post-industrial society often witnesses a rise in the self-employed. Accordingly, training in business fundamentals may lead to an improvement in the quality of the individual labour force and create the conditions required for self-employment.

Labour market information and vocational guidance

The provision of labour market information and vocational guidance assume a significant role irrespective of the level of development of a national economy. Updated news about the possibilities offered by the labour market and assistance in the use of that information is a prerequisite for the improvement of labour market operations. The provision of labour market information and vocational guidance is a prerequisite for young people who have a limited knowledge of the world of work. Different countries apply different strategies for the provision of labour market information and vocational guidance. Labour market information may cover information on current and scheduled employment (categorised in terms of professions, economic sectors or territories), terms of work and revenues, career opportunities, work skills, qualification requirements, training establishments and programmes offered, etc. Professional training consultants employed by non-public organisations, schools, colleges and other educational establishments may provide all the information needed as required by young people. The active use of labour market information and vocational guidance produces a significant impact on the results of the labour market. The use of labour market information by highly skilled consultants may expand the possibilities to find a job, 
reduce the duration of unemployment and boost the efficiency of labour market functioning.

\section{The measurement system used for youth integration into the Lithuanian labour market}

The system has been set up following the results of a survey conducted in 2000 by scientists at the Labour and Social Research Institute within the framework of the project of the Lithuanian Labour Exchange Concerning the Determination of Possibilities for Motivation, Territorial Mobility and Integration of the Youth into the Labour Market via Differentiation of Measures Applied for the Increase of Employment. The survey covered the polling of 2,239 young (16 to 24) unemployed people in various regions of the country both urban and rural.

As mentioned above, the analysis of the experiences of foreign countries has revealed that youth employment, similar to the general employment of the population, is largely dependent on the general economic situation and living standard within that country. Insufficient economic activity leads to a decline in labour demand, whereas low income and social benefits of the population increases labour supply, resulting in a complication of the situation within the labour market. Thus, the most effective measures to increase youth employment are intensive economic development (e.g., Ireland since 1999), the raising of investments in manufacturing, the wideranging creation of new jobs in various economic sectors and regions, and the improvement of labour potential. On the other hand, youth unemployment may be closely associated with the result of the ineffective functioning of the system applied for the formation of the labour force. Insufficient training provided at comprehensive schools, the ignorance of institutions for studies and the subjects of studies and the absence of wanted professions leads many young people to the labour exchange. Accordingly, the prevention of youth unemployment, i.e., the chain of labour force formation, needs to be strengthened alongside the active measures of labour market policy and youth employment.

The system of measures applied for boosting youth employment should encompass the following items (see Figure):

- The improvement of general education

- The improvement of vocational guidance and consulting

- The improvement of primary and continuous professional training

- The development of youth entrepreneurship

- The improvement of active labour market policy measures

- The improvement of youth employment

The assurance of a systematic and complex solution for the improvement of measures applied to the formation of youth labour potential and youth employment is of the utmost importance with regards to solving the problems of youth unemployment, in particular:

\section{The improvement of general education}

Effective general education makes a significant contribution to the solution of problems of youth unemployment, and forms a foundation for the development of human resources. Higher general education guarantees students improved possibilities of professional development and wider prospects for training, and predetermines the acquisition of general

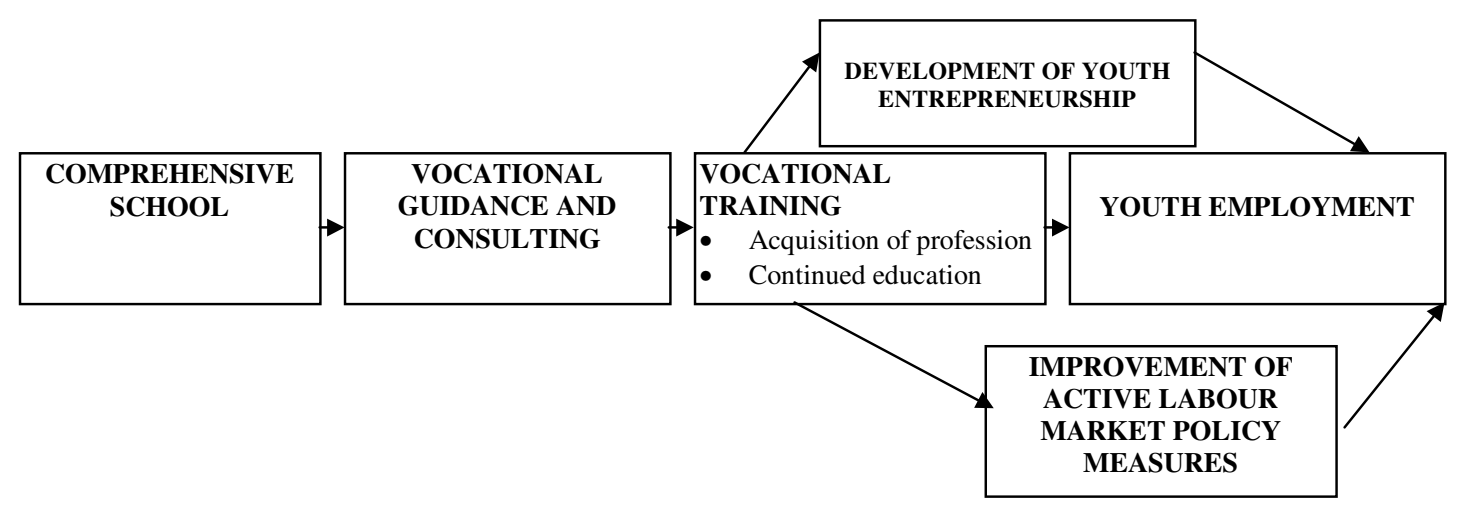

Scheme of youth integration within the labour market 
(key) qualifications ${ }^{2}$. General education is a response to the increase in the complicacy of work processes and the narrowing of the functions of ordinary work. A person's general education defines their cultural and public value, social career and recognition (Lauzackas and Lydeka, 1998, p. 88).

The survey reveals that a significant section of young people are poorly informed about the situation within the Lithuanian labour market, particularly in the region they live. The same can be said about study programmes in comprehensive schools, which don't provide information about the situation within the labour market, unemployment problems, employment, etc., to schoolchildren. The development of personal abilities that can adjust to a variable labour market should begin at school. Pupils need to be acquainted with the changes and problems encountered within the labour market, as well as with the fundamentals of business, management and economics. The organising of additional development may well provide a significant impetus for a better studying of the abovementioned subjects.

With technical and technological advances under way, the universal and general skills and abilities of a personal nature (general qualifications) increase their weight in the structure of employee qualifications steadily.

The results of employer polls conducted in 2000 and 2003 have revealed that alongside the professional skills and qualifications of young employees, employers are equally concerned with their personal qualities (responsibility, honesty, accuracy, etc.) and general abilities. It should be noted that employers from other countries indicate almost identical qualities. For example, representatives of the Danish Confederation of Employers specify a wish for earnest work (non-indifference to work) as the most important quality (Tholsen and Nielsen, 1995).

Thus, general education and other schools should take a more active approach in the development of universal, general skills and abilities of a personal nature, such as creativity, orderliness, sociability, selfdependence, a permanent urge for studies, responsibility, tolerance, etc., as well as the orientation of young people in the direction of conscientious and

'General (key) qualifications' shall mean the most common professional skills, including abstract theoretical thinking, rational activities, creativity, communicability, entrepreneurship etc. General qualifications guarantee the professional adaptability of an employee amid the constant and rapid development of technologies' (Lauzackas and Lydeka, 1997, p.117). honest work, in pursuit of improvements in the supply of the labour force and the potential of human resources.

The importance of high quality professional training does not seem to diminish, either. The inadequate development of young people at comprehensive school reduces their chances to choose a professional training establishment, and largely predetermines their course in life. Accordingly, the question of improvements in the quality of teaching is particularly important. Despite a significant rise in the number of different teaching materials being used, computer systems have a particular value, signifying that teaching materials need to be updated, and schools should be computerised and staffed with the appropriate tutors. For example, a rural 10-year secondary school has no chance of hiring an IT teacher due to the small number of lessons scheduled within the curriculum. Moreover, rural regions suffer from an acute shortage of foreign language and mathematics teachers.

The improvement of professional information, vocational guidance and consulting

Information is the most important (and expensive) value in a post-industrial society. This maxim is significant within the labour market as well. The effective provision of professional information, vocational guidance and consulting (hereinafter referred to as professional consulting) can enable a young person to obtain his or her chosen profession and integrate successfully into the labour market.

As mentioned above, comprehensive schools should develop relationships with employers. The same is true of other social partners, territorial labour exchanges and professional training institutions. The widest possible application of professional capacities of local experts for the maintenance of ties with young people and labour market partners is of the utmost importance. For example, a municipality should be encouraged to organise special days, such as Lawyer Day or Financier Day.

The efficiency of professional consulting services can be guaranteed by due coordination thereof, which should cover all institutions within the sector at national, regional and local levels.

The improvement of primary and continuous professional training

A young person with the correct professional training will be able to secure himself or herself employment and a sufficient income over a longer period of time. However, the survey has revealed that today's professional training institutions are not always able 
to respond to the needs of the market properly. We have singled out the following three core problems:

- The accessibility of professional training ${ }^{3}$

- The compliance of training with the needs of the labour market

\section{- The quality of professional training}

In the opinion of foreign scientists (Ryan, 2001; Heinz, 2000; Koike, 1997; Wyn and Dwyer, 2000), finding a profession is an important requirement for integration into the labour market. Swedish scientist Tomas Korpi (1994) pointed out that young people with a low level of education saw a greater threat of being excluded from the labour market. The experience of Denmark shows that young people who do not strive for knowledge and work during an evolving economic crisis in the country may be pushed out of the labour market forever. Studies conducted in Denmark after the economic crisis of 1977-1981 have confirmed this hypothesis, as young persons up to 30 years of age comprised half of all individuals excluded from the labour market (Worklife Report, 2000). Higher qualifications secure greater employment possibilities, whereas higher education is seen as a virtual guarantee of employment (the data of our survey has revealed that young unemployed people with higher education made up just 1.6 per cent of all unemployed people). Thus, authorities need to guarantee young people the chance to acquire primary professional training provided by a continuous education system (higher schools, colleges and professional schools) complying with the needs of the labour market.

A total of 56 per cent of those polled expressed a wish for training during the survey. Seventy per cent of those willing to study noted that a shortage of funds to finance further training was the main reason preventing them from gaining a profession or improving their professional skills. The problem of training young people is further evidenced by the motives prompting them to choose one or another education establishment. The study has revealed that the choice of education establishment (42 per cent of those polled) was predetermined by an interest in the profession a person wanted to pursue. The second most popular motive was the distance of the education establishment from home, a result of a shortage of financial resources and the financial situation of the

In this scheme, professional training covers the acquisition of a profession at all types of training establishments: higher education schools; colleges; professional schools, and professional training provided by the labour market. household in question. This reason was cited by 34 per cent of those polled, mostly young individuals who have graduated from professional schools and lived in regional areas and remote villages. Meanwhile, this motive seemed less significant for young people living in large cities (Cesnaite and Gruzevskis, 2001).

This situation raises the problem of the accessibility to education for young people living in rural areas (from farming families in particular), and young people from other low-income households. Young people from low-income families do not have the opportunity to choose an educational establishment freely, as they are constrained by funds available and the financial situation of their family.

Low-income households allocate scarce funds for education and their children are not always able to go on to higher education. Accordingly, they find themselves in a group of individuals with poor professional training or a group of non-qualified individuals, encounter numerous problems integrating into the labour market and content themselves with low paid jobs, that is, children find themselves stuck in the same social group as their parents, and society witnesses the formation of a vicious circle of the expansion of poverty and social exclusion, thus increasing the scale of social problems of the country.

The boosting of accessibility to professional and higher education is of the utmost importance, especially for young people from low-income families. Accordingly, local authorities need to establish funds that would offer targeted financial assistance (payment for studies, assignments of scholarships, etc.) to children and young people from families eligible for social support. Local authorities should draft laws allowing young people who made use of this assistance to return to the region for a certain period of time (e.g. for three years) upon completion of their studies, provided that the region could offer relevant employment.

The study has revealed that the problem of professional training which does not reflect fully the needs of the labour market is not diminishing. Half of the respondents ( 50.3 per cent) had a profession but could not find a job. Thus, the analysis of possibilities for professional training and the improvement of professional skills should focus on the compliance of qualitative and quantitative training with the needs of the economy and the prospects of expansion. Current trends within the labour market facilitate the need to distinguish between external and internal compliance. External compliance shows the compliance of profession (trade) and training programme with the 
needs of the economy (trends of economic development). Meanwhile, the internal compliance shows how a profession (trade) complies with the beliefs and preferences of an individual. Notable is the fact that post-industrial society is witnessing a steady rise in the importance of the role of internal compliance, which is seen as a factor behind effective employment. A job complying with the beliefs and needs of an individual increases both job satisfaction and motivation, and makes a positive impact on the results of work and employee-employer relations.

On the other hand, polls of unemployed young people and employers have confirmed the non-decreasing urgency of the problem of practical youth training. The majority of employers admitted dissatisfaction with the professional, and, in particular, the practical training of young people, and, in the event of a vacancy at a company, a total of 84 per cent of employers choose to hire someone with practical experience. However, these qualities of employees cannot be acquired during the process of studying alone, as they are most often acquired during the process of work. Moreover, it should be noted that a new employee encounters adaptation problems that may affect their productivity at the beginning of a new job. Inefficient work raises the costs of employees, thus reducing company profit. The results of the poll of employers Concerning the Satisfaction of Demand in Professional Training of Labour Force and the Qualities Required for Future Employees $^{4}$ have shown that employees adapt to a new job within a period of three months in terms of their qualifications (this term was specified by the majority of employers polled) (Cesnaite, Dilba and Slekys, 1999). Thus, employers are inclined to choose experts with previous work experience, which leads to the emergence of a particular vicious circle. Despite the presence of professional training young individuals often dissatisfy employers with their lack of practical work skills, which can only be acquired through the actual process of work. Thus, the organisation of practical training within a company should develop into one of central forms of cooperation between employers and the professional training establishments (of all levels). Professional training establishments should allocate funds for the organisation of practical training within companies.

4 The poll of employers conducted in 1997 by the Labour and Social Research Institute within the framework of project of the Lithuanian Labour Exchange Concerning the Satisfaction of Demand in Professional Training of Labour Force and the Qualities Required for Future Employees.

\section{The development of youth entrepreneurship}

We have mentioned the development of youth entrepreneurship during the analysis of this outlook on the improvement of general education and professional training. However, we have singled this group of measures for the boosting of employment among young people into a separate item, which does not get the attention it currently requires.

The following elements of the development of youth entrepreneurship may be discerned: business information and training in the fundamentals of a market economy, the support of youth businesses and formation of relevant traditions.

The support of youth entrepreneurship would be most effective if incorporated into the national support programme for small and medium-sized enterprises (SME) (a sub-programme). At present, youth business development faces the same problems as those encountered by the development of the SME sector. Residents lack information about market needs and the projects under implementation, and sense a lack of knowledge and abilities for business organisation. Moreover, the SME sector encounters significant problems while attempting to gain access to banking credits, and often faces problems with the marketing of its products. The unfavourable environment for the development of small and medium-sized business in Lithuania affects the development of youth entrepreneurship as well.

The study data lead to the conclusion that expanding the participation of young unemployed people in business training programmes is of the utmost importance, considering the possibilities of regional labour exchanges. The acquisition of theoretical and, in particular, practical knowledge of business organisation is particularly important for young people. Accordingly, this type of training needs to be organised in close cooperation with local business professionals, employer organisations and experts of local business development agencies.

Authorities should consider more active support of youth non-governmental organisations (NGOs), which create the conditions required for pro-social activities of young people and develop into an effective tool for the building of the skills necessary for work (discipline, creativity, teamwork, etc.). Young people taking part in the activities of NGOs learn the basics of organising their own activities, arrange various business projects, cooperate with social partners, sponsors, etc., get acquainted with legislation, the business environment and the local labour market, and are able to develop and improve their knowledge and 
skills. Thus, the development of assistance for youth business can be associated with the activities of youth NGOs.

\section{Improvement of active labour market policy measures}

The labour market policy in Lithuania targets the priority application of the active measures of the policy. Attempts are made to boost the participation of jobseekers in the programmes of active integration into the labour market each year, with particular attention focused on young people (First Step Programme, Talent Bank Programme, Programme of Supported Employment, intensive consulting and mediation).

The programmes aimed at reducing unemployment among young people should place the emphasis on professional consulting and training. However, temporary forms of employment are just as important amid the insufficiency of the labour force supply. Thus, efforts to improve the active measures of labour market policy should cover the boosting of diversity of the socially beneficial (public) works and the attractiveness thereof for young people (e.g., via cooperation with NGOs, schools and institutions of the Ministry of National Defence). Larger cities and regions (where youth unemployment exceeds the national average) should look for ways to organise socially beneficial (public) works for the young, i.e., to establish youth groups (teams), in which young people would be replaced by young individuals. Groups of this nature could be organised at schools, foster and charity establishments, etc.

\section{Complex improvement of youth employment}

In this article, we have conducted both the direct and indirect analysis of measures that might be applied to help increase youth employment. However, we should also consider the measures that may provide direct assistance for young people applying for vacancies, i.e., to analyse youth employment in the narrow sense.

Efforts to strive for the balance within the supply and demand of the labour force should give attention to regular analysis of the demand within professions and qualifications on the labour market. The authorities should offer employers favourable economic conditions for participation in measures applied for the formation of a labour force and the boosting of youth employment.

Studies have revealed that employers are inclined to fill vacancies with experienced candidates. Only a small percentage (7.6) of employers choose young people. Thus, particular attention should be given to practical youth training and the support of initial employment.
The mobility of the labour force should enable Lithuania, a relatively small country affected by disproportionate socio-economic differentiation, to solve the problems of supply and demand of its labour force. However, it is not intensive enough, therefore, the authorities should make use of and support this quality within young people, the most itinerant group of the population. According to the study's data, almost one-third of respondents would work in another district or city if the necessity arose. The financial resources of the Employment Fund, local authorities and employers (in particular, if larger-scale investment projects could be brought in) could be employed for the implementation of these measures.

\section{Conclusions}

The following aspects should be considered for the development of youth employment:

1. Preference should be given to an effective education policy and vocational training, which should be linked with assistance programmes and a relevant macroeconomic policy able to stimulate the demand within a young labour force.

2. Relevant emphasis should be placed on the structure and distribution of youth demand and supply (professional, territorial, etc.) within the labour market.

3. Authorities need to develop complex directional measures because the problem of youth unemployment will not disappear by itself or by demographic change, in particular within the environment of economic globalisation.

4. Greater attention should be given to certain target youth groups that encounter particular hardships within the labour market, including those who leave school before graduation, individuals without qualifications, ethnic minorities, the disabled, and individuals who face particular problems with finding a job (rural residents, former convicts, etc.).

5. Demands on both the labour market and the education system have a mutual effect via feedback. Accordingly, we can say that the education system largely determines the employment and the market of the population. Thus, the development of education and the general economic system should be linked in compliance with the training of labour force potential within the strategic trends of national development. Different establishments should arrange common forecast scenarios that assess the future demand in professions and qualifications. 
6. The results of studies $[5 ; 14]$ have shown that the improvement of vocational training should place particular emphasis on practical youth training and the improvement of professional skills. The improvement of practical youth training support for young people during their first job should involve the application of subsidies for employers from the Employment Fund or state budget (for 6-12 months) and the reduction of social insurance contributions (for 1-2 years). These measures should be applied with the employer pledging to retain the employment of the employee after the expiry of the term of support or break. Moreover, the application of such measures should be differentiated according to territories and professional groups, considering the structural unemployment in effect.

7. Individual youth subgroups have different chances to participate within the labour market in both developed and emerging economies. Accordingly, these groups should have different measures of labour market policy applied. Individual categories of young people (e.g., young people without compulsory education) have little chance of effectively integrating into the labour market, and so they 'fall out' of it in most cases. Therefore, the system of youth integration into the labour market should be particularly flexible and versatile. Professional youth training should be supported in the first place. However, vocational guidance and consulting should be developed simultaneously, strengthening the motivation for studies and work, and raising the consciousness of young people within the labour market.

8. To sum up, youth unemployment is the outcome of educational policies, vocational training (in the wide sense), social security and the labour market, as well as ineffective economic policies. Thus, to reduce youth unemployment, authorities need to establish a flexible and complex system for the prevention of unemployment among young people, which would encompass all chains of labour force formation and incorporation thereof into work activities.

\section{References}

1. Albrecht, J. W., Holmlund, B., \& Lang, H. (1989). Job search and youth unemployment. European economic review, 33 (Issue 2/3), p. 416-426.

2. Berthelot, Y. (1995). European and General global issues influencing employment and unemployment. In M. Simai,V. Moghadam \& A. Kuddo (Eds.), Global employment: An international investigation into future work. Tokyo: United Nations University Press, p. 3041.

3. Blanchflower, D. G., \& Freeman, R. B. (1996). Growing into work. Employment Outlook. Paris: OECD.

4. Čèsnaitè, B., Dilba, R. ir Šlekys, A. (1999). Aktualūs bedarbiu profesinio mokymo tobulinimo klausimai. Aktualūs socialinès politikos klausimai, 1, 93-105.

5. Čèsnaitè, B., Gruževskis, B. (2001). Jaunimo mokymosi prieinamumo problema. Iš: Tarptautinès konferencijos „Ekonomika ir vadyba - 2001“ medžiaga. Kaunas: Technologija, p. 60-67.

6. Dolto, F. (1985). La cause des enfants. Paris: Robert Lafont.

7. European Commision. (2001). Employment in Europe 2001 - recent trends and prospects. Luxembourg: Office for Official Publications of the European Commision.

8. European Commision. (2000). A Community of fifteen key figures. Luxembourg: Office for Official Publications of the European Commision.

9. Gruževskis B., Okunevičiūtè-Neverauskienė L. (2003). Jaunimo integracijos į darbo rinką problemos. Profesinis rengimas. Tyrimai ir realijos. Kaunas.

10. Heinz, W. R. (2000). Youth transitions and employment in Germany. International Social Science Journal, 52 (Issue 164), p. 162-172.

11. Holm, A., Groes, N., \& Honore Olsen, T. ( 2001). Youth unemployment and oportunities in the labour market the myth of lifelong hysteresis. Review of labour economics \& Industrial relations, 15 (Issue 4), p. 531 -555 .

12. International Labour Conference $88^{\text {th }}$. - Geneve, 1999.

13. Koike, K. (1997). Human Resource Development. Tokyo, the Japan Institute of Labour.

14. Korpi, T. (1994). Escaping Unemployment: studies in the individual consequences of unemployment and labor market policy. Sweeden: Akaddemitryck AB.

15. Laužackas, R., Lydeka, Z. (1997). Techninio mąstymo transformacija ir verslumo ugdymo prielaidos pereinant i rinkos ekonomiką. Ekonomika, 43, p. 98-118.

16. Laužackas, R., Lydeka, Z. (1998). Socioedukologinis profesinio rengimo kaitos Lietuvos įvertinimas. Filosofija ir sociologija, 2, p. 84-891.

17. Lietuvos darbo biržos veikla 2003 metais. LDB, Vilnius, 2004.

18. Lietuvos mokslo ir technologiju baltoji knyga. (2000). Vilnius: Justitia.

19. O’Higgins, N. (1997). The Challenge of Youth Unemployment. The employment training paper, No. 7. Strasbourg: International Labour Office.

20. Seekings, J. H. (1993). Heroes or Villains? Youth Politics in the 1980s. Johannesburg: Ravan Press.

21. Šileika A., Tamašauskienė Z. Investicijos i žmogiškaji kapitalą ir jų efektyvumas. Ekonomika, 2003, Nr. 64. 
22. Tholsen, L., Nielsen, E. (1995). Ko darbdaviai noretų iš būsimujų darbininkų. Švietimo naujoves, 1, p. 50-60.

23. United Nations. (1986). The Situation of the Youth in the 1980s and Prospects and Challenges for the Year 2000. New York: Author.

24. United Nations. (1993). The Global Situation of Youth in the 1990s: Trends and Prospects Youth in the 1980s and Prospects and Challenges for the Year 2000. New York: Author.

25. United Nations. (1994). The Family and Youth: Issues, problems and Opportunities. Occasional Papers series, No11. Viena: Author.

26. Wyn, J., \& Dwyer, P. (2000). New patterns of youth transition in education. International Social Science Journal, 52 (Issue 164), p. 147-160.

27. Youth unemployment: a universal problem. (2000). Worklife report (United Nations), 12 (Issue) 3, p. 6-8. 